\title{
Evaluation of Security Issuse. New Threats Twoards National and International Security.
}

\author{
VILMA SPAHIU, PhD.Cand. \\ Faculty of Social Sciences \& Education, European University of Tirana \\ vspahiu@uet.edu.al
}

\begin{abstract}
The national and international security of states, nowadays, is threatened by many elements or factors, like environmental issues, the spread of mass destruction weapons, wars or ethnic conflicts in developing countries, organized crime, illegal trafficking and the corruption as a side effect of globalization. All these issues are considered as challenges that all the countries must cope with through the drafting of applicable and effective national and global security policies. The aim of this paper is the evaluation of security environment, setting forth various views over new threats or risks. An important part of this study will be the analysing the viewpoints from many different authors in terms of future wars, the possibility of a threat that derives from the collision of great civilizations and also the thread from organized crime and terrorism. Facing all these possible threats, states and governments have to struggle more for finding alternatives that avoid war. This can be reached through their maximal efforts to strengthen their national law and the development of common security policies. Moreover, it is very important for these countries to put to put big efforts for international conflict resolutions, via peaceful instruments and negotiations or the use of diplomacy.
\end{abstract}

Keywords: Security, future wars, collision of civilisation, organised crime and terrorism.

\section{INTRODUCTION}

The word 'Security' occupies a very important place in the fields of International Relations.

The complexity, but also the inability to define it with a single phrase, makes it possible to explain the word with a series of definitions, which become usable depending on the context in which they are used for. This difficulty comes due to fact that has not been accepted a final definition for this term, and moreover the concept of security has been extended more, with the passing years. During the Cold War, security and defence policies dominated national security agendas.

War and peace issues, nuclear intimidation and crisis management, conference diplomacy, weapons control and alliances policies have concerned academics, militaries and researchers, with a professional or personal interest in global politics or in military strategy.

On the contrary, economic, social, human and environmental policies, the management of human resources or the efforts to put boundaries to the population growth, were mostly perceived as sources for concerns, but rarely as threats for national securities. Occasionally, economic policies issues managed to be part of national securities agendas. But in general, security issues and risks or threats related to economical, social, environmental and human matter, were treated as issues that did not belong to the agendas of national or international security.

The post Cold War period has led to big changes in the global geo-strategic environmental, by bringing significant improvements in the relation between states. All this made it to reduce the number of conflicts in the world. The international cooperation between states or other important actors; the positive or negative experiences of some countries; are good lessons that need to be taken under consideration during the drafting of a new effective national security strategy, nowadays. In a world that we are trying to make it as peaceful as possible; in a world where the western democratic premises are being spread increasingly, relatively is believed that the wars will come to an end.

Anyhow, we cannot forget the fact that nothing can be reached without designing a clear strategy, on how we are going to solve this. Thus, the old Latin saying "Si vis Pacis para Bellum" is still valid. 


\section{Different views over new risks}

The international security depends on many elements and factors. The great changes in the international arena during the 90 s brought new risks for local and global security of the world.

International terrorism, organized crime, illegal traffics and corruption, as side effects of globalization, together with the arsenals of weapons left over from the Cold War, have been identified as key risks that threat the national security. The new geopolitical environment, after the Cold War, was characterised by "security issues, closely related to each-other" (Lleshi, 2009: 181). International security depends not only from what we have mentioned above, but also from environmental and cultural issues. Another major problem are the so called weak countries, which are characterised by political instabilities, coups, weak democracy, non-efficient institutions, fragile economy, etc. But how does this implicates international security? Well, as a consequence of no isolating their internal conflicts, because of being weak, because in incapacity, neighbour countries get involved inevitably. This kind of instability that derives from their weakness it tends to be exported in the entire region. (Holsti, 2008: 135). All of above can be appear as threats for national security in a near future.

In the decades that will follow, environmental and security issues are projected to have an important weight. "Stopping the climate changes, the conservation of biodiversity, the struggle against transmittable diseases, the ensuring of clean water, the decrease of poverty, the war against bad nutrition and hunger, the preservation of forests, waters (seas, rivers etc) and other renewable sources that have been overexploited, are just some of the environmental challenges that human nature will have to deal with." (Charles and Kegley, 2009: 517). Other important challenges that will follow the next decades, are not a surprise for the now a day's world, like the eradication of terrorism, states stabilization, stopping the genocide, the prevention of weapons of mass destruction distribution, etc. As we can see, there are many global issues than need to be resolved, but the financial sources are limited. Thus, the world has to put priorities. We cannot solve everything, at the same time. The world has to choose between what is more urgent to be solved.

Even for some time, the media will continue reflecting revolts and violent riots of the "outside world", manly as ethnic and religious conflicts. Nevertheless, when these conflicts will multiply, it will become more visible that there is another factor, at bottom, something that is the main cause for making countries like Nigeria, India, Western Africa and Brazil ungovernable. Western Africa has turned into the symbol of global demographic, environmental and social tensions, where the real "strategic" risk is the criminal anarchy. "Diseases, overpopulation, crime, the lack of resources, immigration movements, the increasing erosion of nation-states and international borders, and also the empowerment of private armies, security firms and national files of narcotics" are all illustrated through the prism of Western Africa. (Kaplan, 2008: 23).

We can mention here Sierra Leone, which according to the map is a nation-state with well-defined borders and with a government that controls the territory of the country. But, within the territory of the government there is a national army that cannot be controlled, that normally threatens travellers and drivers at the check point of national roads. On the other side of the country have been placed two different military units, because of the last war with Liberia and also two rebel groups of Sierra Leone.

Sierra Leone is a micro-cosmos of what is happening, maybe, gradually in all the Western Africa, as well as in the rest of the undeveloped world: the weakness of central governments, the growth of regional and tribal holdings, the uncontrolled spread of different diseases and the growing presence of wars and conflicts. Hereupon, all these countries represent a kind of fragility.

Africa, may be a relevant factor related to the nature of future world politics, as Balkan was 100 years ago, before the two Balkan wars and the First World War. By the time, the risk laid in the dismantlement of empires and in the buildings of nations based on tribes, only. Now the risk is more essential "uncontrolled nature". (Kaplan, 2008: 35).

Africa helps us to understand or to forecast what the borders, the wars, the ethnic policies will be like after some decades, given the fact that the biggest part of Africa is on the verge of disaster.

\section{Future wars}

A viewpoint of international conflicts is to firstly understand that all the countries are looking for power, or better say gaining more power than the other countries. Considering this, the conflict it becomes a general condition that exists between 
countries, leading them to fight for power, better conditions and alliances in the international system. "The power gives states some special benefits, or gives them the ability to draw better conclusions from efforts to agreements on specific issues, which have great importance on their wellness.". (Goldstein, 2003: 195). Much of international conflicts, including those that stand behind dozens of actual wars, are strife for worries and concrete requirements. They are strife for territorial boundaries, ethnic hatred and revolutionary issue. Thus, we can say that the conflicts between countries are not unusual circumstances, but ordinary ones. Conflict can be defined "as a change in the reached preferable conclusions of a circumstance of effort for an agreement." (Po aty, 197).

Meanwhile, in terms of war, it is very difficult to define it, explicitly, therefore it is not how many wars are going on around the world. No matter this, we can distinguish some types of wars, like: Hegemonic war (to establish control over the entire world); total war (for defeating and invading another country); limited war (to achieve some objectives, without having to invade the enemy); civil war (between fractions inside a country) guerrilla war (war without front line). (Po aty, 229-230).

As a conclusion, we can say that the war and other means of international violence are used as impact tools in an attempt to improve the conditions of conflict resolution.

When in International relations are used violent means for influencing, then due to it a variety of types of war may arise, which widely vary on the goals, objectives, shapes, etc.

There are many opinions and analysis for future wars. Wars have been the main focus in the study of International Relations. Wars continue to be the main theme and to this theme are given special attention to the program of the United Nations and regional organizations. Our understanding of contemporary wars is not well served by older analytical approaches. War today is not the same phenomenon as it was in the XIX century or in the ' 30 of the XX century. It has causes and many different features. According to different authors future wars will be caused by various factors. Some authors argue that future wars will not use conventional forces; military forces will be used more for prestige. Beside diplomacy practices, the prestige policy uses also military demonstrations as a mean to achieve its goal.

Because, "military strength is the obvious measure of a nation's power, its demonstration serves to impress others." (Morgenthau, 2008: 99). Prestige is used as a deterrent to war and preparation for war. It is hoped that the prestige of a country will be so great as to prevent the other country to go to war. At the same time it is hoped that if this prestige policy fails, the mobilization of the armed forces before the war blasts, will put the country in a more favorable military position. At the moment, "political and military objectives tend to merge and become two different aspects of the same policy." (Po aty, 102). Authors who defend this thesis see the fight or confrontation of states with their armed forces as unlikely.

There is also a different approach on the conception of future wars. This is otherwise known as the democratic peace. This theory rests on the idea that democratic countries almost never confront each-other in wars. Distribution of democratic governance throughout the world will reduce the probability of wars. History shows that there are multiple reasons to accept this liberal proposal. Many academic quantitative studies of modern international history have shown convincingly that "well established democracies have never gone to wars against each other and only Republics have had a tendency to form unions with lasting peace." (Charles and Kegley, 2009: 513). This liberal principle states that democracy produces more moral values, including freedom, human rights, civil rights, prosperity and especially a capacity to discourage wars between members of these democratic states. Future wars would be curtailed, if more effort were to be done to set as many democratic systems in the world, because these systems share the same values.

The major problems of today's wars are the relations within the country rather than the relations between countries. New and weak states are the main location of today and future wars. We can very well manage to understand contemporary wars by studying the birth of states and how they are governed. Among the fundamental problems is that "of legitimacy, the principle of religion belief and the principle of natural community". (Holst, 2008: 4). Fights break out mainly in the states based on these last two principles, because they are exclusive. Contradictions between exclusive principles of legitimacy and that of social and demographic composition in many post-colonial and post-Soviet societies create weak states and eventually the raising of wars.

"Wars are not made for the sake of foreign policy, security or status, but for the sake of statehood, governance, and the role and status of the nations and communities that are within the states". (Stoessinge, 2007: 19). Weak states are characterized by a "lack of proper order, represent institutional weaknesses for the implementation of a national policy and are characterized by political instability, centralization of power and unconsolidated democracy." (Fawcett, 2009: 145) 
Weak or failed states have returned to the most important problem of international order. Weak or failed states "abuse human rights, provoke humanitarian disasters and attack their neighbors." (Fukuyama, 2008: 139).

There is also another important factor, such as the proliferation of weapons of mass destruction, which could affect future wars. According to some researchers, the risk that threatened humanity by the use of weapons of mass destruction would come to an end with the end of the Cold War, but today these weapons continue to pose a threat to the entire world. Despite the constantly efforts that have been done to prevent the proliferation of weapons of mass destruction, it has been observed that some states and non-state actors see these weapons as an alluring asset to their arsenal. The world in which we live today, where there exist the possibility of proliferation of weapons of mass destruction; the risks with which we are faced are very disturbing.

"Chemical, biological, nuclear and radioactive weapons are not only becoming part of sustainable arsenals of states, but they can also fall into terrorist hands." (Collins, 2009: 340). This actually makes the situation very alarming. Because, for example, an attack with chemical weapons on a major sport event, can kill thousands of people. International terrorist networks, have all the resources and materials to build and to use chemical, biological and radioactive weapons. The existence of these weapons of mass destruction constantly increases the possibility of national and international insecurity of states.

Future wars may be caused by a possible clash of civilizations, i.e. a clash of cultures. Civilizations, however big they are, both great and common, can always be located on a map. An essential part of their reality depends on the limitations or advantages of their geographical setting. Civilization means "space, land, relief, climate, vegetation, animal species; priority given in advance or acquired". (Braudel, 1987: 45). Each civilization exports and imports cultural goods. Today the spread of cultural goods has accelerated dramatically. We can also say that there is "no civilizations without society", the two notions belong to the same reality. (Ibid, 51). So basically, every civilization explains the vision of the world it represents.

Civilization is only a whole of technical and practical knowledge, a collection of means to act on nature, while cultures are normative principles, values, ideals; therefore are mentalities which are less sensitive to passing of time, they change slowly. As the civilizations are different, even their actions are justified by religion and not by reasoning. This shows that religion plays the most powerful role in the civilizations. Almost always, civilizations are enfolded or strangled by religion, the supernatural or the magical aspect.

In the second half of the XX century we have a revival of various religions such as Christianity, Islam, Judaism, Hinduism, Buddhism, Orthodoxy, etc. It was precisely this kind of resurrection that gave a new meaning to these traditional religions. In a more general view, this religious revival in the whole world is a reaction against the secularization and moral relativism. We can't help without mentioning the events of 11 September, which in a way were cultural clashes between the East and the West. However, to understand this clash, we must understand the context of a new international system that has emerged. This new system is called globalization.

"Globalization can be defined as the irreversible integration of markets, transportation and communication systems to unprecedented proportions, enabling corporations, individuals and states to stretch further (Friedman, 2003: 6). The essential feature of globalization is the integration. The world has become more intertwined, and today the success or failure of a company or a state depends more and more on the person or thing that you are connected with. This system is characterized by a single word: "web", i. e, worldwide Internet network. So, in a broader sense, we have passed from an international system based on the separation and walls, (Cold War) to a system based more and more on integration and the web. The globalization system is built on the basis of three aspects, which interfere and influence each other. The first is the traditional balance of power between nations and states. In the system of globalization, the United States remains the only superpower, while all other nations depend on it to some extent or another.

The second important aspect in the system of globalization is that between nation-states and global markets. These global markets are composed of millions of investors from all around the world that move their money with one touch of a button. These are called "Electronic Bundles", which have as their headquarter, important global financial centers such as Wall Street, Hong Kong, London and Frankfurt, which are Supermarkets". (Friedman, 2003: 9). The actions taken by these "Ectronic Bundles" and by the SuperMarkets" may have tremendous impact on nation-states, even bring the downfall of governments. The thirs aspect, which is unquestionably the most important in terms of the events of 11 September, was between individuals and nations-state. 
Globalization, tearing down the numerous walls that restricted contacts between peoples, and also connecting the world by means of networks, give individuals more power than ever in history to affect markets and nations-state alike, the opportunity to use the Internet to communicate instantly even from great distances, enabling the use of the web to transfer money or to find weapons projects that normally should have been under the control of the states. Globalization represents a tremendous mean, through which individuals can amplify their strength and ability to act directly on the world stage, without the mediation of any state. "In every field of activity, immediate opportunity to get and give information and the opportunity to put that in use increases the number of actors that matter and reduces the number of those who exercise great authority" (Matthews, 1997: 51). As a result, today we don't have only superpowers, "SuperMarkets", but we also have super-empowered individuals who are fully able to act strongly on the world stage and become a danger to international security.

Those who defend the argument that the war will come as a result of the clash of civilizations argue that, in this new world, "the most important conflicts will not be between social classes (rich and poor) or between other groups determined by the economic aspect, but between peoples belonging to different cultural complexes ". "Intertribal wars and ethnic conflicts will occur within civilizations". (Huntington, 2004: 28-29). Future conflicts will arise from cultural factors and not by economic or ideological factors.

However, I think such a clash of civilizations is impossible, so the attention of the state should be focused more on other issues that threaten more international security such as, organized crime, transnational crime, terrorism etc.

\section{Organized crime and terrorism}

Organized crime and terrorism are not new phenomena or occurrences. Countries such as Italy, Japan, China and the United States of America, faced organized crime during most part of the 20th century. Also, the history of humanity has known individuals, groups, organizations and even whole countries as terrorists.

Terrorist activities have flourished mainly in periods of crisis, anarchy, chaos, wars, or smuggling and due to the lack of security conditions, law and order. Terrorism was sheltered, supported or implemented by totalitarian, dictatorial and authoritarian countries, which, through acts and terrorist activities have and continue to achieve their domestic and international goals. Individuals, organizations and terrorist regimes constitute a joint network against peace, security, stability and democracy. The definition of terrorism has sparked long and complicated debates in the theoretical and international practice. There are many definitions regarding this term, more than 150.

For some terrorism is violence for political purposes, others see it as a psychologically violence. But, generally, the theoretical idea is aligned around this definition: "Terrorist activities are called those criminal, inhuman activities undertaken by individuals, groups or criminal organizations against individuals or groups of innocent citizens, in private or public environments that, through crime, murder, massacres cause panic in public life for certain political and economic purposes and benefits". (Bashkurti, 2008: 179).

Terrorism and organized crime are increasingly being transformed into more serious threats to national and international security. The growth of organized and transnational crime has come as a result of globalization. The process of globalization, has served as a mitigating factor for the operation of criminal and terrorist activities. Globalization has acted as a facilitator for all kinds of illegal activities such as drug and arms trafficking, as well as the use of violence against innocent civilians. So globalization has created favorable conditions to organized crime and terrorism in achieving greater benefits and opportunities.

Organized crime and terrorism are composed by people who behave as rational actors. According Clausewitz, "organized crime is essentially a continuation of business by criminal means." While, "terrorism is the continuation of given policy by using violence" (Hoxha, 2010: 3). Terrorists may be political individuals, groups or movements which have as their main goal the changes. They use violence on a wider scale to achieve this change. Today, organized crimes as well as terrorism constitute a serious threat to national and international security of states, as both these violent criminal activities, use violence and the corruption of state officials to achieve greater financial benefits. However, one of the biggest concerns for governments is a possible collaboration between organized crime and terrorism. This feared collaboration would make it even more difficult the governments' war against those. Because, through this cooperation, both criminal activities could obtain even bigger benefits, they could regenerate their resources and would increase their effectiveness, causing a greater 
risk for the national security of states and their global system as a whole. As such phenomena, as organized crime and terrorism, increasingly threaten global security; countries are trying to develop policies to combat them. But designed policies, are not minimizing as should, criminal activities, because organized crime has taken international dimensions. Today, crime lives in a world without borders. Also, another factor that is affecting the proper implementation of these policies relates to the large number of targets and goals that have different states, while criminal and terrorist organizations have only one main goal.

However, countries should try harder and should have more patience to combat and prevent the spread of various criminal activities, because they really pose a serious threat to the national and international security of states.

\section{Conclusions \& Recommendations}

Now a days, national and international security are threatens by many factors, which play an important role in preventing the accomplishment of national security objectives. Regardless the different opinions or analysis over the possibility of future wars, possible threats, whom of course might turn into elements that increase the global insecurity and hinder the establishment of peace, we can say that the operation organized/transactional crime brings more implications, than any other issue, on global security. This is due to the fact that the organised/transactional crime affects the weakening of democratic institutions, the weakening of the economy and of the society in general. States must be aware and must understand that all the elements of their power have to be used in order to design effective strategies in the struggle against organized and transactional crime, starting with their roots. Certainly, this struggle cannot end in a short period, it will need time. They have to be patient in order to affront this big security challenge. In case they put maximal efforts to minimise, step by step, the activity of criminal groups, there are many chances to arise as winners from this challenge, creating like this a safer world for all its citizens.

\section{REFERENCE}

[1] Bashkurti, Lisen: "Krizat ndërkombëtare", Mirgeeralb, Tiranë 2008.

[2] Braudel, Fernard: "Gramatikë e qytetërimeve”, Shtëpia e Librit dhe Komunikimit, Tiranë 1987.

[3] Collins, Alan: "Studime bashkëkohore të sigurisè", UET Press, Tiranë 2009.

[4] Charlss W. Kegley, Jr: "Politikat Botërore", UFO Press, Tiranë 2009.

[5] Friedman, Thomas: "Bota në kohën e terrorizmit ", IDK, Tiranë 2003.

[6] Fukuyama, Francis: "Ndërtimi i shtetit", AllS, Tiranë 2008.

[7] Goldstein, Joshua S: "Marrëdhëniet Ndërkombëtare", Dituria, Tiranë 2003.

[8] Hoxha, Luan: "Çështjet bashkëkohore të Strategjisë ndërkombëtare”, Leksioni Nr. 6, UET, Tiranë 2010.

[9] Huntington, Samuel P: "Përplasja e qytetërimeve", Logos-A, Shkup, Prishtinë, Tiranë 2004.

[10] Kalevi J. Holsti: "'Shteti, lufta dhe gjëndja e luftës", ISN, Tiranë 2008.

[11] Kaplan, Robert D: "Anarkia që po troket", AllS, Tiranë 2008.

[12] Louise, Fawcett: "Marrëdhëniet Ndërkombëtare", UET Press, Tiranë 2009.

[13] Lleshi, Abaz: "Gjeopolitika e Ballkanit dhe Perspektivat në Rajon”, Geer, Tiranë 2009.

[14] Matthews, Jessica: "Power shift", Foreign Affairs 76:1 (January-February), 1997.

[15] Morgenthau, Hans J: "Politika ndërmjet kombeve", AllS, Tiranë 2008.

[16] Stoessinge John G: "Përse kombet shkojnë në luftë", AllS, Tiranë 2007. 